FEDERAL RESERVE BANK OF SAN FRANCISCO

WORKING PAPER SERIES

\title{
The Effects of Unconventional and Conventional U.S. Monetary Policy on the Dollar
}

\author{
Reuven Glick, \\ Federal Reserve Bank of San Francisco \\ Sylvain Leduc, \\ Federal Reserve Bank of San Francisco
}

May 2013

Working Paper 2013-11

http://www.frbsf.org/publications/economics/papers/2013/wp2013-11.pdf

The views in this paper are solely the responsibility of the authors and should not be interpreted as reflecting the views of the Federal Reserve Bank of San Francisco or the Board of Governors of the Federal Reserve System. 


\title{
The Effects of Unconventional and Conventional U.S. Monetary Policy on the Dollar
}

\author{
Reuven Glick and Sylvain Leduc
}

\author{
May 16, 2013 \\ Economic Research Department \\ Federal Reserve Bank of San Francisco
}

\begin{abstract}
:
We examine the effects of unconventional and conventional monetary policy announcements on the value of the dollar using high-frequency intraday data. Identifying monetary policy surprises from changes in interest rate futures prices in narrow windows around policy announcements, we find that surprise easings in monetary policy since the crisis began have had significant effects on the value of the dollar. We document that these changes are comparable to the effects of conventional policy changes prior to the crisis.
\end{abstract}

JEL classification:

Keywords: monetary policy, quantitative easing, dollar, exchange rate

We thank Stefania D'Amico for providing us with her measure of monetary policy surprises. We also thank Jeremy Pearce for excellent research assistance. The views expressed here are those of the authors and do not necessarily represent those of the Federal Reserve Bank of San Francisco or the Board of Governors of the Federal Reserve System. Email: Reuven.Glick@sf.frb.org, Sylvain.Leduc@sf.frb.org. 


\section{Introduction}

Since the onset of the financial crisis in 2007 , the Federal Reserve has introduced new monetary policy measures to stabilize financial markets and mitigate the effects of the crisis on economic activity. These so-called unconventional policy tools have been necessary both because of the extraordinary nature of the financial crisis and because the federal funds policy rate was quickly dropped to its effective lower bound of near zero percent by the end of 2008. As a result, the Federal Reserve turned to large-scale asset purchases (LSAPs) — also commonly called quantitative easing — and to greater forward guidance about the future path of monetary policy to achieve its dual mandate of price stability and maximum employment.

These new policy tools come with a significant amount of uncertainty regarding their effectiveness, particularly whether the standard transmission channels of monetary policy through financial asset markets work as well as they did in the past. An important channel through which changes in monetary policy affect the economy is the value of the currency. There is much empirical evidence, for instance, documenting that the dollar typically depreciated following declines in the federal funds rate in the pre-crisis period (see, for instance, Clarida and Galì 1994; Eichenbaum and Evans, 1996; Faust and Rogers, 2003; Scholl and Uhlig, 2008; and Bouakez and Normandin, 2010).

In this paper, we examine how the U.S. dollar has reacted to changes in unconventional monetary policy since the federal funds rate reached its zero lower bound in December 2008 and how this effect compares to those following changes in conventional monetary policy in the preceding period. To do so, we use high-frequency, intraday data to study the dollar's movements against the currencies of major U.S. trading partners in time intervals immediately following monetary policy announcements by the Federal Reserve. The use of intraday data 
enables us to better isolate the response of the dollar to monetary announcements from other possible determinants. In addition, to control for the likelihood that market participants anticipate policy changes, we follow Wright (2011) and construct surprise changes in monetary policy using changes in long-term Treasury rate futures around the time of policy announcements. We employ a similar methodology for the pre-crisis period when the federal funds rate was above the zero lower bound: we use changes in federal funds rate futures around Federal Open Market Committee (FOMC) announcements about the federal funds rate target to measure conventional policy surprises. ${ }^{1}$

We document that the U.S. dollar depreciated significantly following both conventional and unconventional monetary policy surprises. Looking first at the effects of unconventional monetary policy since the end of 2008, we find that a one standard deviation surprise easing in unconventional policy leads to a roughly 40 basis point (bp) decline in the value of the dollar within 60 minutes. In turn, we find that in the conventional policy period the dollar depreciated in response to federal funds rate easing surprises, with a one standard deviation surprise easing leading to about a $6 \mathrm{bp}$ decline in the value of the dollar in the hour after announcements.

Clearly, our surprise changes in conventional and unconventional monetary policy are not directly comparable since the former captures unanticipated changes in a very short-term interest rate, while the latter captures unanticipated changes in long-term interest rates. To enable comparison of unconventional and conventional monetary policy effects, we analyze the comovements in federal funds and long-term rates during the period when the funds rate was above its lower bound. This yields an adjustment parameter that we use to rescale the measure of unconventional policy surprises into equivalent fund rate surprises. The resulting adjusted

\footnotetext{
${ }^{1}$ See also Kuttner (2001), Bernanke and Kuttner (2005), Fleming and Piazzesi (2005), Gurkaynak, Sack, and Swanson (2005), Faust et al. (2007), and D'Amico and Farka (2011) for the effects of monetary policy surprises during the period before the financial crisis.
} 
coefficients indicate that a one standard deviation surprise unconventional policy easing leads to a 5 to 6 bp depreciation in the dollar, magnitudes that are comparable to those for federal funds rate surprises in the pre-crisis period. This suggests that monetary policy has the same bang-perunit of surprise as previously and that the exchange channel of monetary policy is still working as effectively as in the past.

Our paper adds to a growing and active literature on the effects of unconventional monetary policy. Starting with Gagnon et al. (2011), several papers have attempted to analyze the effectiveness of recent monetary policy actions with event studies of Federal Reserve announcements (see, for instance, Neely (2010), Krishnamurthy and Vissing-Jorgensen (2011), D'Amico et al. (2012), Glick and Leduc (2012), Hamilton and Wu (2012), and Li and Wei (2012)). By emphasizing the effects on the U.S. exchange rate, our work is closest to that of Neely (2010), who looks at the impact of announcements of large-scale asset purchases by the Federal Reserve between November 2008 and November 2009. Our focus is different, as we contrast the effect of surprise changes in unconventional policy on the exchange rate to those from changes in the federal funds rate. In addition, our work differs in that it controls for market expectations of possible changes in monetary policy, which is important to precisely identify the surprise component of policy announcements. Abstracting from anticipation effects may otherwise lead to incorrect inference, as forward-looking market participants may have already responded to the policy change by the time it is announced. We also have the benefit of working with a longer sample that includes policy announcements during the first, second, and third rounds of large-scale asset purchases between 2008 and 2012.

The paper is organized as follows. In Section 2 we describe our data and measures of monetary surprises. Section 3 presents the benchmark empirical results for the effects of 
unconventional and conventional monetary policy on the value of the dollar. Robustness exercises are reported in Section 4. Section 5 concludes.

\section{Identification of Monetary Policy Events and Surprises}

\subsection{Identifying monetary policy surprises}

We examine the effects of monetary policy surprises on the value of the U.S. dollar during the period when monetary policy was conventionally conducted via changes in the federal funds rate target and the more recent period when policymakers relied on other unconventional policy tools, such as large-scale asset purchases and communications about future policy actions. Our sample period for conventional monetary policy actions extends from February 1994, when the FOMC began issuing a press release after every meeting and every change in policy, until October 2008, just before the federal funds target rate reached its lower bound. The period characterized by unconventional monetary policy actions spans the period from November 2008 to the end of our sample in January $2013 .^{2}$

The extent to which an announcement affects the currency when it is released to the public largely depends on whether or not market participants expect the announcement. If market participants anticipate the content of the news, then no additional information is revealed at the time of the announcement and the value of the dollar should not move as a result. Therefore, controlling for market participants' expectations is crucial for our analysis. To identify surprise changes in monetary policy, we use changes in interest rate futures in a tight time interval around monetary policy news.

\footnotetext{
${ }^{2}$ The Federal Reserve lowered the federal funds rate to effectively zero in December 2008. However, it had already signaled the introduction asset purchases in speeches in November 2008. As a result, we opted to end our sample for the conventional policy period in October 2008.
} 
For the conventional policy period, given that monetary policy is conducted via changes in the target for the federal funds rate, we follow the approach proposed in Kuttner (2001), and use the change in federal funds rate futures constructed by D'Amico and Farka (2011) to identify monetary policy surprises. ${ }^{3}$ To better isolate the influence of changes in monetary policy, the procedure uses intraday tick data to measure the change in federal funds rate futures from 10 minutes before a policy announcement to 20 minutes after. ${ }^{4}$ This strategy provides a good measure of monetary policy shocks if possible interest risk premia remain relatively constant around policy announcements.

However, our method of identifying monetary policy surprises with the changes in federal funds rate futures is not a viable strategy when the federal funds rate is at zero and monetary policy is conducted through unconventional means. Consequently, for the unconventional policy period, we modify our procedure to use a different measure. Given the Federal Reserve's recent emphasis on lowering long-term interest rates to implement monetary policy, we focus on the change in long-term Treasury rate futures for the period from November 2008 onward. More specifically, we follow Wright (2011) and use the change in the principal component of the two-, five-, ten, and thirty-year Treasury rate futures, again measured during a 30-minute window, from 10 minutes before an announcement to 20 minutes after. ${ }^{5,6}$ Throughout,

\footnotetext{
${ }^{3}$ Following Kuttner (2001), we assume that the federal funds futures rate can be expressed as a weighted average of the rate prevailing so far in the month and the expected rate for the rest of the month, plus a risk premium. Assuming a constant risk premium implies that our monetary surprise measure can be defined as the change in the futures rate, adjusted by the scale factor, $D /(D-d)$, where $D$ is the number of days in the month and $d$ is the day in the month of the monetary policy announcement. We use this definition as long as the announcement occurs earlier than the last seven days of the month. If the announcement falls in the last seven days, the surprise is computed as the unadjusted change in the next-month fed funds futures contract to avoid unduly large adjustment factors.

${ }^{4}$ This window represents the "narrow" window in D'Amico and Farka (2011). They also considered wider windows, extending as long as 60 minutes after announcements. We use the wider windows as a robustness check. ${ }^{5}$ The surprises were constructed from changes in the returns on the on the two-, five-, ten-, and thirty-year bond futures contracts, divided by the duration of the cheapest-to-deliver security in the futures basket, as gathered from Bloomberg. In our principal components analysis of these duration-adjusted yield changes, we take the eigenvector corresponding to the largest eigenvalue, i.e., the first principal component, and multiply each yield change by its respective eigenvector component. It should be noted that the bulk of Federal Reserve asset puchases during the
} 
we demean the conventional and unconventional policy surprises, scale them to have a standard deviation of 1 , and indicate monetary easing with a positive sign and monetary tightening with a negative sign.

The news events in the conventional policy period consist of 125 FOMC announcements, 119 following scheduled meetings and six following intermeeting communications. The series includes unscheduled meetings only if the announcements included a change in the federal funds target. For instance, the measure excludes the unscheduled meetings in 2007 because the Federal Reserve did not announce a change in the federal funds rate at those meetings. ${ }^{7}$

For the period characterized by unconventional monetary policy period, we use all FOMC announcements between November 2008 and January 2013 - including both regularly scheduled and some unscheduled meetings. We also include selected speeches given by Chairman Bernanke in which he signaled possible policy changes, particularly those suggesting modifications to the Federal Reserve intentions to buy long-term assets. The announcements that refer to large-scale asset purchases are listed in Table 1. The complete sample, which includes these LSAP announcements as well as others announcements following FOMC meetings, consists of a total of 40 observations. ${ }^{8}$ Our sample thus encompasses announcements used in

third LSAP round involved mortgage-backed securities. However, we do not have intraday data on these securities since they typically are traded over the counter.

${ }^{6}$ Wright (2011) uses a baseline surprise window from 15 minutes before a given Federal Reserve announcement until 1 hour and 45 minutes after. Our surprise window $(-10,+20)$ was chosen to match that of the narrow measure of D'Amico and Farka (2011) for fed fund surprises employed below. A wider surprise window is considered as a robustness exercise.

${ }^{7}$ The unscheduled meetings included in the measure are: April 18, 1994; October 15, 1998; January 3, 2001; April 18, 2001; January 22, 2008; and October 8, 2008. The series excludes the unscheduled meetings of August 10 and August 17, 2007, which communicated Fed awareness of events but did not announce policy changes, as well as March 11, 2008. Like Bernanke and Kuttner (2005) and D'Amico and Farka (2011), we also omit the scheduled meeting observation of September 17, 2001, due to the extreme idiosyncratic nature of this episode which coincided with the resumption of trading following the September 11 terrorist attacks.

${ }^{8}$ In addition to the four LSAP-related speeches by Chairman Bernanke cited in Table 1, our sample also includes a speech on August 26, 2011, when the Chairman stated the Fed was considering all of its options, though he was not explicit about additional policy actions. We do not separately break out FOMC announcements related to the Maturity Extension Program involving the sale of short-term Treasuries to purchase longer-term assets for the Federal Reserve's balance sheet. These announcements are included in the non-LSAP FOMC events in the sample. 
other studies on the effects of large-scale asset purchases. For instance, the five announcements associated with the first round of large-scale asset purchases (LSAP1) between November 25, 2008, and March 18, 2009, correspond to those used by Gagnon et al. (2011) and Neely (2010). Similarly, the five announcements for the second round of asset purchases (LSAP2) from August 10 to November 3, 2010, are similar to those used by Wright (2011), Krishnamurthy and Vissing-Jorgensen (2011), and Glick and Leduc (2012). In addition, our analysis encompasses announcements associated with the third round of asset purchases (LSAP3) initiated in September 2012.

\subsection{Intraday exchange rate movements}

For our analysis, we use intraday data on currency futures prices from Tickdata for the days in our announcement sample. The data set contains minute-by-minute tick prices on foreign exchange contracts involving the U.S. dollar with several currencies, including the euro, yen, pound, and Canadian dollar. ${ }^{9}$ In 2010 , these four currencies accounted for over 70 percent of all spot dollar transactions ${ }^{10}$ and over 60 percent of all swap and futures dollar transactions (BIS, 2010), while the countries issuing these currencies accounted for about 40 percent of U.S. bilateral trade transactions.

One advantage of using intraday data that is particularly relevant for monetary policy announcements is that it enables us to better isolate their effects. For instance, many studies of large-scale asset purchases by the Federal Reserve since 2008 have relied on daily data to assess the effect of unconventional monetary policy on the price of financial assets (see, for instance, Gagnon et al. (2011)). This approach assumes that the market effects from a monetary announcement will dominate effects from any other information released that day. However, this

\footnotetext{
9 These data are based on contracts traded on the Chicago Board of Trade.

${ }^{10}$ The euro, yen, pound, and Canadian dollar accounted for 39, 15, 12, and 7 percent of spot transactions, respectively.
} 
assumption may be particularly troublesome for asset prices such as exchange rates, which react naturally to news from around the world. Hence, it is more difficult to precisely uncover potential links between monetary policy announcements and movements in currency values using daily data, as the effects of other news events on the U.S. dollar are likely to confound those from monetary policy.

Consequently, we look at movements in the value of the U.S. dollar against foreign currencies in relatively narrow time intervals. Consistent with our identification of the-monetary policy surprises, we use response windows around monetary policy announcements of 30 minutes (10 minutes before, until 20 minutes after) and 70 minutes (10 minutes before, until 60

minutes after). Using tight time intervals helps us isolate the effects of the monetary announcements from other possible determinants of currency values, assuming these announcements rapidly influence the views of market participants and are quickly reflected in the value of the dollar. For comparison, we also report results extending the response surprise windows to 1440 minutes, i.e., one day, after announcements.

\section{Results}

\subsection{Changes in value of the dollar during LSAP rounds}

We begin our analysis by reporting the raw, i.e., actual, changes in the value of the dollar during the three rounds of LSAPs. Figure 1 illustrates the intraday behavior of bilateral exchange rates on selected LSAP announcement days. As shown in panel A, the dollar depreciated sharply against all four currencies on December 16, 2008, immediately after the 2:15pm FOMC announcement about the details of LSAP1. The dollar depreciation was smaller following the selected FOMC announcements about LSAP2 and LSAP3. 
Table 2 reports changes in the average value of the dollar vis-à-vis the pound, Canadian dollar, euro, and yen during a response window starting 10 minutes before announcements until 20 minutes after. ${ }^{11}$ Observe that the dollar depreciated against these currencies in response to announcements during all three LSAP rounds. (The appreciation of the dollar against the yen during LSAP3 is an exception, possibly because of the yen's strong appreciation in the week before the September 13, 2012, FOMC meeting and market talk about possible Bank of Japan intervention.)

On a trade-weighted basis, the dollar depreciated by an average of 62,24 , and 14 bps after announcements about LSAP1, LSAP2, and LSAP3, respectively. ${ }^{12}$ The relatively small effect under LSAP3 does not necessarily imply that the Fed's LSAP3 monetary policy actions were ineffective, since the markets may have anticipated these announcements and incorporated them into asset prices. This motivates the need to control for the extent to which the announcements were surprises to the market.

For comparison, the table also shows total changes in the interday value of the dollar against major currencies, also known as the "narrow nominal index," as measured over the 24hour period from the end of floor trading on the day prior to each announcement (usually 2:30pm EST) and the end of floor trading on the announcement day. Note that the interday changes during LSAP1 are comparable to the intraday changes measured over the event window periods. In the case of LSAP2, however, the narrow dollar actually appreciated. This suggests that narrow response windows are desirable to control for other events as much as possible when ascertaining the effects of monetary policy on the exchange rate.

\footnotetext{
${ }^{11}$ We use the price of the nearest, most heavily traded futures contract on each announcement day.

${ }^{12}$ We construct trade weights from Direction of Trade data in 2011 on U.S. bilateral exports and imports with the U.K., Canada, Eurozone, and Japan, with calculated weights of 0.07, 0.41, 0.39, and 0.13, respectively. Results from taking simple averages are comparable.
} 


\subsection{Effects of unconventional monetary policy}

We estimate the effects of surprise monetary policy announcements on the value of the dollar using the following specification:

$$
\Delta S_{t, w}=a+b \cdot M P S_{t}+\varepsilon_{t}
$$

where

$M P S_{t}=$ monetary policy announcement surprise at time $t$,

$\Delta S_{t, w}=$ change in the log of the exchange rate in response to this announcement over a response window of size $w$,

$\varepsilon_{t}=$ stochastic error term that captures the effects of other factors that influence the exchange rate.

As discussed in Section 2, positive values of MPS are defined to indicate monetary easing surprises, while the exchange rate is defined as units of foreign exchange per U.S. dollar, so that a decrease in $S$ indicates a depreciation of the dollar. Hence, a negative $b$ coefficient estimate is consistent with the finding that monetary policy easing leads to a depreciation of the dollar.

Table 3 reports coefficients from regressions of the value of the dollar on our measure of unconventional policy surprises, using response windows of lengths ranging from 10 minutes before the announcement to $w=20,60,1440$ minutes (i.e., one day) after. Constants are included in the regressions, though they generally are insignificantly different from zero.

The analysis finds that the dollar depreciates against all currencies in response to these surprises, with a one standard deviation surprise leading to a 36 bp decline in the trade-weighted value of the dollar within 20 minutes. ${ }^{13}$ This effect appears to persist over time, with a $58 \mathrm{bp}$ depreciation after one day, though the role of other possible determinants of exchange rates may

\footnotetext{
${ }^{13}$ In terms of basis points, an unconventional monetary policy surprise of one percentage point (100 bp) causes a 3.0 percent decline in the value of the dollar within 20 minutes. Converting this result into the effects of a standardized surprise by dividing it by the standard deviation of unconventional monetary surprises over the sample period, 12.1 bp, gives the result we report in Table 3 .
} 
not be ruled out with this longer response window. The effects vary across individual currencies as well as across time, with the effects lowest for the Canadian dollar and highest for the euro. In the latter case, for example, a one standard deviation unconventional policy surprise leads to a 44 bp increase after 20 minutes and a $71 \mathrm{bp}$ increase after one day.

The scatter plots in Figure 2 support the negative slope coefficient results in Table 3 and also illustrate the distribution of the sign and magnitude of monetary policy surprises and corresponding dollar value changes across the sample. Observe that the sample includes both negative, i.e., unexpected tightening, as well as positive, i.e., unexpected easing, monetary surprises (with the largest positive surprises occurring on two announcement days during the first round of asset purchases, January 18, 2008, and March 18, 2009, the latter in the lower right portion of the plot). The chart also displays a clear negative relationship between the size of surprise easing and the value of the U.S. dollar, as captured by the negative slope of the regression line. In other words, the U.S. dollar depreciates more the greater the surprise unconventional policy easing. We address the effect of excluding LSAP1 observations in a robustness exercise below.

\subsection{Effects of conventional monetary surprises}

To assess the magnitude of the exchange rate effects of unconventional policy surprises, it is useful to compare them with the effects of conventional monetary policy during the period when the federal funds target rate was the main policy tool, before the target rate reached the lower bound.

Table 4 reports the actual movements in the dollar following FOMC announcements during the pre-crisis period of February 1994 to October 2008, grouped by the direction and magnitude of the change in the federal funds rate. Observe that the dollar generally appreciated in response to rate hikes, more so with increases greater than $25 \mathrm{bp}$. Correspondingly, the dollar 
generally depreciated in response to rate cuts of greater than $25 \mathrm{bp}$. The response of the dollar to rate cuts of $25 \mathrm{bp}$ is an exception to the pattern with the dollar appreciating on average.

Actual rate changes do not control for the extent to which markets anticipated the effects of monetary policy announcements. Table 5 reports the dollar response coefficients to surprise changes in the federal funds rate, analogous to the analysis in Table 3. As expected, the dollar depreciated in response to federal funds easing surprises, with a one standard deviation surprise easing in the federal funds rate leading to a change in the trade-weighted dollar of about a 6 bps after 20 minutes and 10 bps after a day.14 It should be noted that the significance of the coefficients for some currencies is somewhat lower than in the case of the unconventional policy surprises. Moreover, the $\mathrm{R}_{2}$ of all of these regressions is fairly low, indicating that other factors played a large role in exchange rate movements.

\subsection{Comparison of dollar effects from unconventional and conventional policy surprises}

Because the surprise changes in our unconventional policy measure involve changes in long-term interest rates, their effect on the U.S. exchange rate is not directly comparable to those following surprises changes in the federal funds rate, an overnight interest rate. To enable comparison of unconventional and conventional monetary policy effects, we convert our unconventional policy surprises into equivalent federal funds rate surprises. To do so, we first extend our measure of unconventional policy surprises back to 1994 and examine how it typically reacted following a surprise change in the federal funds rate during the period when the

funds rate was above its lower bound. Clearly, for this period, our measure of unconventional

policy does not proxy for changes in monetary policy. However, it will be affected by changes in 14 terms of basis points, a conventional monetary policy surprise of one percentage point ( 100 basis points) causes a 0.67 percent decline in the value of the dollar within 20 minutes. Converting this result into the effects of a standardized surprise by dividing it by the standard deviation of conventional monetary surprises over the period, 9.2 basis points, gives the result we report in Table 5. 
monetary policy, as measured by unanticipated changes in federal funds rate futures. We examine this relationship by regressing our measure of unconventional policy surprises on the measure of conventional policy surprises over the period February 1994 to October $2008 .^{15}$ The estimated slope coefficient, which we define by the parameter $\gamma$, captures the average relationship between unconventional policy surprises and conventional policy surprises. We then use this parameter to rescale the unconventional policy measure of long-term rate surprises during the zero lower bound period into equivalent fund rate surprises. This conversion enables us to report the relative responses of the dollar to conventional and unconventional policy surprises in comparable terms.

In our benchmark case, shown in the top panel of Table 6 , we estimate $\gamma$ over the sample period from February 1994 to October $2008^{16}$ and obtain an estimated value of 0.146 , implying that a one standard deviation surprise easing in the fed funds rate is associated with a 0.146 unit change in the unconventional policy surprise measure. Multiplying the response coefficients to unconventional policy surprises in Table 3 by this parameter renders them into terms comparable to federal funds rate surprises. For example, the estimated coefficient for the response of the trade-weighted dollar to a one standard deviation surprise easing in unconventional policy after 20 minutes, -36.39 , is equivalent to an adjusted dollar response of $5.3 \mathrm{bp}(=-36.29 * 0.146)$ to a one standard deviation surprise easing in the federal funds rate. We consider alternative estimates of the adjustment parameter $\gamma$ in Section 4.

Table 7 reports the results of adjusting the estimated coefficients from Table 3 for unconventional policy surprises, together with the estimated coefficients from Table 5 for the conventional policy surprises, and the ratio of the two numbers. It shows that an unconventional

\footnotetext{
${ }^{15}$ October 15, 1998, is excluded because government securities markets were closed at the time of the FOMC announcement that day.

${ }^{16}$ March 11, 2008, is excluded because the FOMC announcement was made after the closure of long-term Treasury markets, preventing us from constructing our unconventional policy measure for this date.
} 
policy surprise easing leads to a $5.3 \mathrm{bp}(5.8 \mathrm{bp})$ depreciation in the trade-weighted dollar after 20 (60) minutes and $8.5 \mathrm{bp}$ after a day. These magnitudes are comparable to those for federal fund rate surprises, with the ratios of the effects of unconventional to conventional policy being roughly 0.9 across response windows. This suggests that unconventional monetary policy has the same "bang" per unit of surprise as the federal funds rate previously had and that the exchange channel of monetary policy is still working effectively.

\section{Robustness Analysis}

We assess the robustness of our results to factors such as the size of the window over which the monetary surprises are calculated, the composition of surprise events, and the magnitude of the adjustment parameter. Table 8 reports the results of several exercises for the response of the trade-weighted dollar.

\subsection{Wider surprise windows}

We first consider the implications of a wider window over which both the conventional and unconventional policy surprises are calculated, going from 10 minutes before announcements until 60 (rather than 20) minutes after. As shown in panel B, we find that the exchange rate response - a 6 bp change in the dollar within 60 minutes following a standardized surprise - is virtually the same as with the benchmark narrow window.

\subsection{Excluding LSAP1 events}

Figure 2 suggests that much of the power of the negative relation between unconventional policy surprises and the dollar may come from the LSAP1 episodes, which appeared to surprise markets the most. As shown in panel $\mathrm{C}$ of Table 8, excluding LSAP1 events from the sample indeed implies an estimated dollar response in the hour after unconventional policy announcements - a 3 to 4 bp change in the dollar following a surprise- 
that is less than the $6 \mathrm{bp}$ decline following both unconventional and conventional surprises in the benchmark. ${ }^{17}$ It should also be noted that there is virtually no response to unconventional policy surprises a day later, though the effects over the longer response window may be confounded by the effects of other shocks affecting exchange rates. ${ }^{18}$

\subsection{Alternative adjustment parameter}

The adjustment parameter $\gamma$ is key to comparing the effects of unconventional and conventional monetary policy. We next consider alternative estimates of the adjustment parameter used to rescale the effects from unconventional policy into comparable conventional policy effects. Table 6 compares the implications of alternative approaches to estimating this parameter.

Panel A reports our benchmark results from regressing the unconventional policy surprises on the conventional policy surprises over the period February 1994 to October 2008, which yields an adjustment parameter value of 0.146 . In considering the sensitivity of this estimate to the sample period, we note that the onset of the recent financial crisis actually occurred in mid-2007 and intensified with the collapses of Bear Stearns in March 2008 and Lehman Brothers in September 2008. This prompted Federal Reserve responses, including the establishment of special lending facilities, even before the Fed fully dropped the funds rate to its lower bound and began resorting to large-scale asset purchases. In panel B of Table 6 we estimate the same regression over the period February 1994 to November 2007, ending just

\footnotetext{
${ }^{17}$ Supporting results for individual currencies are available upon request.

${ }^{18}$ In unreported regressions, we estimated the effects of monetary policy announcement surprises across individual LSAP rounds as well as other policy event days during the unconventional policy period. Though the limited degrees of freedom for individual LSAP rounds call into question their statistical significance, we find that the tradeweighted dollar depreciated by 43, 72, and 5 basis points, respectively, in response to a one-standard deviation quantitative easing surprise during LSAP1, LSAP2, and LSAP3, respectively. Thus after controlling for the surprise content of announcements, LSAP3 displayed the smallest bang per unit of surprise. Moreover, the dollar depreciation during LSAP3 is significantly less than that following other, non-LSAP, monetary policy announcements, when the dollar depreciated on average by 26 basis points.
} 
before the establishment of special liquidity facilities, starting with the term auction facility in December 2007. This yields a higher adjustment parameter, 0.267.

However, observe that the $\mathrm{R}^{2}$ and the significance level of the $\gamma$ estimate in the regressions reported in panels $\mathrm{A}$ and $\mathrm{B}$ are each low, with the estimated $\gamma$ being insignificant over the benchmark sample and significant only at the 10 percent level over the sample ending in November 2007. To investigate further, Figure 4 provides a scatter plot of unconventional and conventional policy surprises over the period from February 1994 to October 2008. Our focus is on the outlier observations on the right-hand side of the figure, episodes characterized by big easing surprises in the federal funds rate target but little evidence of correspondingly big changes in unconventional policy surprises. Further inspection indicates that these episodes are associated with announcements after unscheduled FOMC intermeetings—April 18, 1994; January 3, 2001; April 18, 2001; January 22, 2008; and October 8, 2008—identified separately in Figure $4 .^{19}$ Panel C of Table 6 reports the results of excluding these outliers from the sample used to estimate the adjustment parameter. Observe that the adjustment parameter estimate, 0.375 , is more than double the benchmark estimate and is significant at the 5 percent level. ${ }^{20}$

The differential effects of intermeeting announcements have been noted in other studies. Fleming and Piazzesi (2005), for example, analyze monetary policy effects over the period February 1994 to December 2004 using a sample that includes three of the episodes we examine-April 18, 1994; January 3, 2001; and April 18, 2001—as well as September 17, 2001,

\footnotetext{
${ }^{19}$ Other intermeetings we exclude are October 15, 1998, following the Russian ruble devaluation and near collapse of Long-Term Capital Management for which we were unable to construct our unconventional policy measure because of the closure of the Treasuries markets at the time of the announcement (at 3:15pm); and March 11, 2008, which is omitted from the D'Amico and Farka (2011) data set we use. Our analysis does include more recent unscheduled meetings on January 22 and October 8, 2008. Both of these events occurred before the federal funds rate reached its lower bound and are included in our conventional rate period that ends with October 2008. We treat all Bernanke speeches as scheduled since market analysts had advance notice of these events.

${ }^{20}$ A regression (not reported) which includes intermeeting observations with an intercept and interactive slope dummy indicates there is a statistically significant shift in the intercept term but no change in the slope associated with the outliers.
} 
and October $15,2008 .^{21} 22$ They find that Treasury rates responded particularly slowly to the announcements on these days. They suggest several reasons why intermeeting moves might be important in explaining the market's weak response: intermeeting target rate easing surprises tend to occur in relatively uncertain environments; tend to be larger; and may have a larger "signaling" component than other announcements about economic weakness, dampening bond demand, and the easing of long-term rates, or alternatively may take a longer time to be digested and processed by markets. Consequently the association of conventional and unconventional policy surprises may have been affected.

Panels D and E of Table 8 report the effects of using our alternative estimates of $\gamma$ on the adjusted dollar response to unconventional policy surprises. Estimation from ending the sample in November 2007, before the establishment of special facilities began, implies responses in the trade-weighted dollar on the order of 10 to $11 \mathrm{bps}$ within the first hour in response to a one standard deviation surprise easing. These magnitudes are larger than the estimated 5 to $6 \mathrm{bp}$ response to conventional policy easing surprises over the same interval. Thus in this case the effects of unconventional policy surprises exceed those of conventional ones by roughly 60 percent across all of the response windows. Still larger are the adjusted effects when we omit the intermeetings from the sample, reported in panel E. In this case the dollar rises by roughly 14 to 15 bps within the hour and 22 bps after a day. Panel E of the table also reports the effects of reestimating the conventional policy effects on the dollar with the intermeetings excluded. Observe

\footnotetext{
${ }^{21}$ Gurkaynak et al. (2005) and Bernanke and Kuttner (2005) also exclude September 17, 2001, on the grounds that asset market responses at that time reflect not just the effects of the FOMC announcement but also the fact that it was the first day that the federal funds rate market was open after the September 11 terrorist attack.

22 The October 15, 1998, event followed the Russian ruble devaluation and the near collapse of Long-Term Capital Management.
} 
that these effects are also higher compared with the benchmark. ${ }^{23}$ We find that the tradeweighted dollar depreciates in this case by 12,17 , and 10 bps compared to 6,6 , and 10 bps in the benchmark after 20,60, and 1440 minutes, respectively. Thus dropping the intermeeting observations raises the impact of both types of policy surprise on the dollar, with the relative magnitude of their effects varying over the response window. The ratio of unconventional effects to conventional effects is 1.15 after 20 minutes and 0.89 after 60 minutes.

\section{Conclusion}

Using intraday data, we examine the effects of unconventional monetary policy on the U.S. dollar. Our results suggest that the exchange rate effect of the new policy has been as effective as it was when the Federal Reserve could rely on changes in the federal funds rate to conduct monetary policy. In particular, we find that monetary policy now has much the same bang per surprise on the value of the dollar as previously: roughly 6 bp change per unit surprise.

That said, although unconventional monetary policy remains effective at moving the value of the dollar, it remains more difficult to assess the overall impact on U.S. net exports. For instance, it is quite possible that the response of U.S. net exports to dollar depreciation may have been less than in the past because of greater uncertainty surrounding economic recoveries around the world, most particularly in Europe, which is still battling its debt crisis. We leave this important issue to future research.

\footnotetext{
${ }^{23}$ Regressions for the dollar response to conventional policy surprises to individual currencies without the outliers are available upon request.
} 


\section{References}

Bank for International Settlements (2010). Triennial Central Bank Survey Foreign Exchange and Derivatives Market Activity in 2010, Annex Table D.1

Bernanke, Ben and Kenneth Kuttner (2005). "What Explains the Stock Market's Reaction to Federal Reserve Policy?" Journal of Finance 60(3), 1221-1257.

Bouakez, H. and M. Normandin (2010). "Fluctuations in the Foreign Exchange Market: How Important Are Monetary Policy Shocks?” Journal of International Economics.

Clarida, R. and J. Gali (1994). "Sources of Real Exchange Rate Fluctuations: How Important Are Nominal Shocks?” Carnegie Rochester Conference Series on Public Policy 41,1-56.

D’Amico, S., English, W, Lopez-Salido, D, Nelson, E (2012). “The Federal Reserve's LargeScale Asset Purchase Programs: Rationale and Effects." Finance and Economics Discussion Paper 2012-37. Board of Governors of the Federal Reserve System.

D'Amico, S., and M. Farka (2011). "The Fed and the Stock Market: An Identification Based on Intraday Futures Data," Journal of Business and Economic Statistics.

Eichenbaum, M, and C. Evans (1996). "Some Empirical Evidence on the Effects of Monetary Policy Shocks on Exchange Rates." Quarterly Journal of Economics.

Faust, J. and J. Rogers (2003). "Monetary Policy's Role in Exchange Rate Behavior.” Journal of Monetary Economics.

Faust, J., Rogers, J., Wang, S., Wright, J. (2007). "The High Frequency Response of Exchange Rates and Interest Rates to Macroeconomic Announcements." Journal of Monetary Economics

Fleming, Michael and Monika Piazzesi (2005). "Monetary Policy Tick-by-Tick," manuscript.

Gagnon, J., Raskin, M., Remache, J., Sack, B (2011). "The Financial Market Effects of the Federal Reserve's Large-Scale Asset Purchases," International Journal of Central Banking.

Glick, Reuven. and Sylvain Leduc (2012). "Central Bank Announcements of Asset Purchases and the Impact on Global Financial and Commodity Markets," Journal of International Money and Finance.

Gurkaynak, Refet, Brian Sack, and Eric Swanson (2005). "Do Actions Speak Louder Than Words? The Response of Asset Prices to Monetary Policy Actions and Statements," International Journal of Central Banking, May.

Hamilton, J., and Wu, J (2012). "Effects of Index-Fund Investing on Commodity Futures Prices." Working Paper. 
Krishnamurthy, A., A. and Vissing-Jorgensen ( 2011). "The Effects of Quantitative Easing on Interest Rates". Working Paper, Northwestern University, Kellogg School of Business.

Kuttner, Kenneth (2001). "Monetary Policy Surprises and Interest Rates: Evidence from the Fed Funds Futures Market," Journal of Monetary Economics 47 (3), 523-544.

Li, C. and M. Wei (2012). "Term Structure Modelling with Supply Factors and the Federal Reserve's Large Scale Asset Purchase Programs." Finance and Economics Discussion Paper 2012-37. Board of Governors of the Federal Reserve System.

Neely, Christopher (2010). “The Large-Scale Asset Purchases Had Large International Effects," Federal Reserve Bank of St. Louis Working Paper 2010-018C.

Scholl, A. and H. Uhlig (2008). "New Evidence on the Puzzles: Results from Agnostic Identification on Monetary Policy and Exchange Rates." Journal of International Economics.

Wright, Jonathan H. (2011). "What Does Monetary Policy do to Long-Term Interest Rates at the Zero Lower Bound?" NBER Working Paper 17154. 
Table 1. Federal Reserve LSAP Announcements

\begin{tabular}{|c|c|c|c|c|}
\hline Date & Time EST & Round & Event & Description \\
\hline $11 / 25 / 2008$ & $8: 15 \mathrm{am}$ & 1 & $\begin{array}{l}\text { Initial LSAP1 } \\
\text { announcement }\end{array}$ & $\begin{array}{l}\text { FOMC announces intended purchases } \\
\text { of } \$ 100 \text { billion in GSE debt and up to } \\
\$ 500 \text { billion in MBS. }\end{array}$ \\
\hline $12 / 1 / 2008$ & $1: 40 \mathrm{pm}$ & 1 & $\begin{array}{l}\text { Bernanke } \\
\text { Speech in } \\
\text { Austin, Texas }\end{array}$ & $\begin{array}{l}\text { Chairman Bernanke says that the Fed } \\
\text { could purchase long-term Treasuries. }\end{array}$ \\
\hline $12 / 16 / 2008$ & $2: 15 \mathrm{pm}$ & 1 & $\begin{array}{l}\text { FOMC } \\
\text { Statement }\end{array}$ & $\begin{array}{l}\text { FOMC first mentions } \\
\text { possible purchase of long- } \\
\text { term Treasuries. }\end{array}$ \\
\hline $1 / 28 / 2009$ & $2: 15 \mathrm{pm}$ & 1 & $\begin{array}{l}\text { FOMC } \\
\text { Statement }\end{array}$ & $\begin{array}{l}\text { FOMC says that it is ready to expand } \\
\text { agency debt and MBS purchases, as } \\
\text { well as purchase long-term Treasuries. }\end{array}$ \\
\hline 3/18/2009 & $2: 15 \mathrm{pm}$ & 1 & $\begin{array}{l}\text { FOMC } \\
\text { Statement }\end{array}$ & $\begin{array}{l}\text { FOMC says it will purchase an } \\
\text { additional } \$ 750 \text { billion in agency MBS, } \\
\text { increase its purchases of agency debt } \\
\text { by up to } \$ 100 \text { billion, and buy up to } \\
\$ 300 \text { billion in long-term Treasuries. }\end{array}$ \\
\hline $8 / 10 / 2010$ & $2: 15 \mathrm{pm}$ & 2 & $\begin{array}{l}\text { FOMC } \\
\text { Statement }\end{array}$ & $\begin{array}{l}\text { FOMC states that it will continue to } \\
\text { roll over the Federal Reserve holdings } \\
\text { of Treasury securities as they mature. }\end{array}$ \\
\hline $8 / 27 / 2010$ & 10:00am & 2 & $\begin{array}{l}\text { Bernanke } \\
\text { Speech at } \\
\text { Jackson Hole }\end{array}$ & $\begin{array}{l}\text { Chairman Bernanke suggests that the } \\
\text { FOMC is likely to buy longer-term } \\
\text { securities. }\end{array}$ \\
\hline $9 / 21 / 2010$ & $2: 15 \mathrm{pm}$ & 2 & $\begin{array}{l}\text { FOMC } \\
\text { Statement }\end{array}$ & $\begin{array}{l}\text { FOMC states that the Federal Reserve } \\
\text { will continue to roll over its holdings of } \\
\text { Treasury securities as they mature. }\end{array}$ \\
\hline $10 / 15 / 2010$ & $8: 15 \mathrm{am}$ & 2 & $\begin{array}{l}\text { Bernanke } \\
\text { Speech at } \\
\text { Boston Fed }\end{array}$ & $\begin{array}{l}\text { Chairman Bernanke indicates easing is } \\
\text { to be continued. }\end{array}$ \\
\hline $11 / 3 / 2010$ & $2: 15 \mathrm{pm}$ & 2 & $\begin{array}{l}\text { FOMC } \\
\text { Statement }\end{array}$ & $\begin{array}{l}\text { FOMC states its intention to purchase } \\
\$ 600 \text { billion more in longer-term } \\
\text { Treasury securities by the end of the } \\
\text { second quarter of } 2011 \text {. }\end{array}$ \\
\hline $8 / 31 / 2012$ & 10:00am & 3 & $\begin{array}{l}\text { Bernanke } \\
\text { Speech at } \\
\text { Jackson Hole }\end{array}$ & $\begin{array}{l}\text { Chairman Bernanke announces } \\
\text { intention for further action. }\end{array}$ \\
\hline $9 / 13 / 2012$ & $12: 30 \mathrm{pm}$ & 3 & $\begin{array}{l}\text { FOMC } \\
\text { Statement }\end{array}$ & $\begin{array}{l}\text { FOMC says it will engage in more } \\
\text { policy accommodation by purchasing } \\
\text { additional agency mortgage-backed } \\
\text { securities at a pace of } \$ 40 \text { billion per } \\
\text { month }\end{array}$ \\
\hline $12 / 12 / 2012$ & $12: 30 \mathrm{pm}$ & 3 & $\begin{array}{l}\text { FOMC } \\
\text { Statement }\end{array}$ & $\begin{array}{l}\text { FOMC extends longer-term Treasury } \\
\text { security purchases and announces } \\
\text { numerical threshold targets. }\end{array}$ \\
\hline
\end{tabular}


Table 2. Average Intraday Change in Value of Dollar per Monetary Announcement, November 2008 - January 2013 (in basis points)

\begin{tabular}{lccccc} 
& LSAP1 & LSAP2 & LSAP3 & Other & All \\
\hline British pound $\$$ Sanadian dollar/\$ & -66 & -19 & -13 & 8 & -7 \\
Euro/\$ & -62 & -27 & -17 & 4 & -10 \\
Japanese yen/\$ & -69 & -25 & -18 & 10 & -7 \\
\hline Intraday trade-weighted \$ & -42 & -13 & 5 & 10 & 0 \\
No. obs. & 5 & -24 & -14 & 7 & -7 \\
\hline Memo: Interday narrow \$ & -59 & 22 & -26 & -13 & -15 \\
\hline
\end{tabular}

Notes: Table reports intraday change in foreign exchange value of the dollar for window from 10 minutes before announcements to 20 minutes after. Negative figures indicate depreciation of the dollar. 
Table 3. Regression of Change in Value of Dollar on

Unconventional Policy Surprises, November 2008 - January 2013

\begin{tabular}{|c|c|c|c|}
\hline & \multicolumn{3}{|c|}{ Response Window, in minutes } \\
\hline & +20 & +60 & +1440 \\
\hline \multicolumn{4}{|l|}{ British pound $/ \$$} \\
\hline Unconventional Policy surprise & $\begin{array}{c}-38.70 * * * \\
(4.50)\end{array}$ & $\begin{array}{c}-40.08 * * * \\
(6.75)\end{array}$ & $\begin{array}{c}-50.32 * * \\
(24.08)\end{array}$ \\
\hline Constant & $\begin{array}{l}-1.76 \\
(4.02)\end{array}$ & $\begin{array}{l}-5.23 \\
(7.01)\end{array}$ & $\begin{array}{c}-1.25 \\
(15.83)\end{array}$ \\
\hline $\mathrm{R}^{2}$ & 0.70 & 0.44 & 0.22 \\
\hline No. obs. & 40 & 40 & 36 \\
\hline \multicolumn{4}{|l|}{ Canadian dollar $/ \$$} \\
\hline Unconventional Policy surprise & $\begin{array}{c}-28.11 * * * \\
(3.65)\end{array}$ & $\begin{array}{c}-33.88 * * * \\
(6.83)\end{array}$ & $\begin{array}{c}-47.13^{* *} \\
(19.36)\end{array}$ \\
\hline Constant & $\begin{array}{l}-6.21 \\
(4.32)\end{array}$ & $\begin{array}{r}-11.97 \\
(7.98)\end{array}$ & $\begin{array}{c}12.83 \\
(16.33)\end{array}$ \\
\hline $\mathrm{R}^{2}$ & 0.52 & 0.31 & 0.19 \\
\hline No. obs. & 40 & 40 & 36 \\
\hline \multicolumn{4}{|l|}{ Euro/\$ } \\
\hline Unconventional Policy surprise & $\begin{array}{c}-43.79 * * * \\
(3.67)\end{array}$ & $\begin{array}{c}-48.23 * * * \\
(7.86)\end{array}$ & $\begin{array}{c}-71.00 * * * \\
(21.90)\end{array}$ \\
\hline Constant & $\begin{array}{l}-1.14 \\
(5.13)\end{array}$ & $\begin{array}{l}-7.24 \\
(7.85)\end{array}$ & $\begin{array}{c}4.32 \\
(20.13)\end{array}$ \\
\hline $\mathrm{R}^{2}$ & 0.65 & 0.49 & 0.28 \\
\hline No. obs. & 40 & 40 & 36 \\
\hline \multicolumn{4}{|l|}{ Japanese yen $/ \$$} \\
\hline Unconventional Policy surprise & $\begin{array}{c}-44.81 * * * \\
(5.25)\end{array}$ & $\begin{array}{c}-40.12 * * * \\
(5.67)\end{array}$ & $\begin{array}{c}-70.25 * * * \\
(10.77)\end{array}$ \\
\hline Constant & $\begin{array}{c}5.81 \\
(3.64)\end{array}$ & $\begin{array}{c}5.01 \\
(3.92)\end{array}$ & $\begin{array}{c}-7.15 \\
(11.72)\end{array}$ \\
\hline $\begin{array}{l}\mathrm{R}^{2} \\
\text { No. obs. }\end{array}$ & $\begin{array}{c}0.78 \\
40\end{array}$ & $\begin{array}{c}0.72 \\
40\end{array}$ & $\begin{array}{c}0.54 \\
36\end{array}$ \\
\hline \multicolumn{4}{|l|}{ Trade-weighted \$ } \\
\hline Unconventional Policy surprise & $\begin{array}{c}-36.39 * * * \\
(3.24)\end{array}$ & $\begin{array}{c}-39.89 * * * \\
(6.66)\end{array}$ & $\begin{array}{c}-58.43 * * * \\
(17.98)\end{array}$ \\
\hline Constant & $\begin{array}{l}-2.50 \\
(3.97)\end{array}$ & $\begin{array}{l}-7.48 \\
(6.71)\end{array}$ & $\begin{array}{c}6.13 \\
(14.62)\end{array}$ \\
\hline $\mathrm{R}^{2}$ & 0.68 & 0.47 & 0.32 \\
\hline No. obs. & 40 & 40 & 36 \\
\hline
\end{tabular}

Note: Robust standard errors in parentheses. ${ }^{*}, * *, * *$ denote significance at $10 \%, 5 \%, 1 \%$ levels, respectively. Exchange rate changes are in basis point units and surprises are in standardized units, so the figures in the table can be interpreted as effect of a one standard deviation surprise on the exchange rate in basis points. A negative coefficient indicates dollar depreciation. 
Table 4. Average Intraday Change in Value of Dollar per Announcement, February 1994 - October 2008 (in basis points)

\begin{tabular}{lccccc} 
& \multicolumn{5}{c}{ Federal Funds Rate Change } \\
& $>+25 \mathrm{bp}$ & $+25 \mathrm{bp}$ & $=0$ & $-25 \mathrm{bp}$ & $<-25 \mathrm{bp}$ \\
\hline British pound/\$ & 21 & 4 & -3 & 4 & -1 \\
Canadian dollar/\$ & 0 & -3 & -2 & 2 & -4 \\
Euro/\$ & 28 & 1 & -6 & 2 & -10 \\
Japanese yen $/ \$$ & 12 & 2 & -3 & 5 & -6 \\
\hline Intraday trade-weighted $\$$ & 12 & 0 & -4 & 3 & -6 \\
No. obs. & 5 & 26 & 67 & 12 & 15 \\
\hline Memo: Interday narrow $\$$ & 8 & 2 & 1 & -11 & -26 \\
\hline
\end{tabular}

Notes: Table reports intraday change in foreign exchange value of the dollar for window from 10 minutes before announcements to 20 minutes after, conditional on change in the federal funds rate. Negative figures indicate depreciation of the dollar. 
Table 5. Regression of Change in Value of Dollar on Conventional Policy Surprises, February 1994 - November 2008

\begin{tabular}{|c|c|c|c|}
\hline & \multicolumn{3}{|c|}{ Response Window, in Minutes } \\
\hline & +20 & +60 & +1440 \\
\hline \multicolumn{4}{|l|}{ British Pound $/ \$$} \\
\hline \multirow[t]{2}{*}{ Conventional Policy surprise } & $-5.61 * *$ & -6.10 & -0.55 \\
\hline & $(2.58)$ & $(3.88)$ & $(6.45)$ \\
\hline \multirow[t]{2}{*}{ Constant } & 0.99 & 0.27 & -5.34 \\
\hline & $(1.80)$ & $(2.26)$ & $(5.87)$ \\
\hline $\mathrm{R}^{2}$ & 0.07 & 0.06 & 0.00 \\
\hline $\mathrm{N}$ & 125 & 125 & 124 \\
\hline \multicolumn{4}{|l|}{ Canadian Dollar $/ \$$} \\
\hline \multirow[t]{2}{*}{ Conventional Policy surprise } & $-5.74 * * *$ & $-5.00 * *$ & $-12.00 * *$ \\
\hline & $(1.71)$ & $(2.49)$ & $(5.62)$ \\
\hline \multirow[t]{2}{*}{ Constant } & -1.10 & -2.92 & 4.09 \\
\hline & $(1.45)$ & $(1.88)$ & $(4.53)$ \\
\hline $\mathrm{R}^{2}$ & 0.11 & 0.05 & 0.06 \\
\hline $\mathrm{N}$ & 125 & 125 & 124 \\
\hline \multicolumn{4}{|l|}{ Euro $/ \$$ or $D M / \$$} \\
\hline \multirow[t]{2}{*}{ Conventional Policy surprise } & $-7.93 * *$ & -7.40 & $-12.90 *$ \\
\hline & $(3.87)$ & $(6.98)$ & $(7.27)$ \\
\hline \multirow[t]{2}{*}{ Constant } & -1.33 & -1.95 & -3.54 \\
\hline & $(2.38)$ & $(3.77)$ & $(6.69)$ \\
\hline $\mathrm{R}^{2}$ & 0.08 & 0.04 & 0.03 \\
\hline $\mathrm{N}$ & 124 & 87 & 123 \\
\hline \multicolumn{4}{|l|}{ Japanese Yen $/ \$$} \\
\hline \multirow[t]{2}{*}{ Conventional Policy surprise } & -2.54 & $-6.39 * *$ & -3.94 \\
\hline & $(2.59)$ & $(2.98)$ & $(8.27)$ \\
\hline \multirow[t]{2}{*}{ Constant } & -0.84 & 1.41 & -1.81 \\
\hline & $(2.11)$ & $(2.51)$ & $(7.57)$ \\
\hline $\mathrm{R}^{2}$ & 0.01 & 0.05 & 0.00 \\
\hline $\mathrm{N}$ & 125 & 125 & 124 \\
\hline \multicolumn{4}{|l|}{ Trade-weighted $\$$} \\
\hline \multirow[t]{2}{*}{ Conventional Policy surprise } & $-6.18 * * *$ & -6.12 & $-9.88^{*}$ \\
\hline & $(2.08)$ & $(3.81)$ & $(5.63)$ \\
\hline \multirow[t]{2}{*}{ Constant } & -1.03 & -2.24 & 0.13 \\
\hline & $(1.54)$ & $(2.57)$ & $(4.55)$ \\
\hline $\mathrm{R}^{2}$ & 0.11 & 0.07 & 0.04 \\
\hline $\mathrm{N}$ & 124 & 87 & 123 \\
\hline
\end{tabular}

Note: Robust standard errors in parentheses. ${ }^{*}, * *, * * *$ denote significance at $10 \%, 5 \%, 1 \%$ levels, respectively. Exchange rate changes are in basis point units and surprises are in standardized units, so the figures in the table can be interpreted as effect of a one standard deviation surprise on the exchange rate in basis points. A negative coefficient indicates dollar depreciation. 
Table 6. Alternative Estimates of Adjustment Parameter $\gamma$ for Unconventional Policy Surprises

Dependent variable: Unconventional policy surprise

a. Benchmark (Feb. 1994-Oct. 2008)

$\begin{array}{lcc}\gamma & 0.146 & (0.135) \\ \text { Constant } & -0.008 & (0.088) \\ \mathrm{R}^{2} & 0.020 & \end{array}$

No. obs.

124

b. End sample pre-special facilities (Feb. 1994-Nov. 2007)

$\begin{array}{lcc}\gamma & 0.267^{*} & (0.153) \\ \text { Constant } & -0.033 & (0.090) \\ \mathrm{R}^{2} & 0.055 & \end{array}$

$\mathrm{R}^{2} \quad 0.055$

No. obs. 114

c. Intermeetings excluded (Feb. 1994 - Oct. 2008)

$\begin{array}{lcc}\gamma & 0.375 * * & (0.147) \\ \text { Constant } & 0.015 & (0.089) \\ \mathrm{R}^{2} & 0.062 & \end{array}$

No. obs.

119

Note: Table reports results of regressing unconventional monetary surprises on conventional monetary surprises, with estimated slope coefficient $\gamma$. Surprises are in standardized units, so the table figures can be interpreted as the effect of a onestandard deviation change in the magnitude of conventional policy surprise on standardized unconventional surprises. Robust standard errors in parentheses. $*, * *$ denote significance at the 
Table 7. Comparison of Dollar Value Responses to Adjusted Unconventional and Conventional Policy Surprises

Response Window, in minutes

$\begin{array}{lll}+20 & +60 & +1440\end{array}$

\begin{tabular}{|c|c|c|c|}
\hline British pound $/ \$$ & & & \\
\hline Policy surprise & & & \\
\hline Adj. Unconventional & $-5.64 * * *$ & $-5.84 * * *$ & $-7.33 * *$ \\
\hline Conventional & $-5.61 * *$ & -6.10 & -0.55 \\
\hline Ratio & 1.00 & 0.97 & 13.33 \\
\hline
\end{tabular}

Canadian dollar $/ \$$

Policy surprise

Adj. Unconventional $\quad-4.10 * * *-4.94 * * * \quad-6.87 * *$

Conventional $\quad-5.74 * * * \quad-5.00 * * \quad-12.00 * *$

$\begin{array}{llll}\text { Ratio } & 0.73 & 1.00 & 0.57\end{array}$

Euro or DM/\$

Policy surprise

Adj. Unconventional $\quad-6.38 * * *-7.03 * * *-10.35 * * *$

Conventional $\quad-7.93 * * \quad-7.40 \quad-12.90 *$

$\begin{array}{llll}\text { Ratio } & 0.80 & 0.94 & 0.81\end{array}$

Japanese yen $/ \$$

Policy surprise

Adjusted Unconventional $-6.53 * * *-5.85 * * *-10.24 * * *$

$\begin{array}{llll}\text { Conventional } & -2.54 & -6.39 * * & -3.94\end{array}$

$\begin{array}{llll}\text { Ratio } & 2.54 & 0.91 & 2.58\end{array}$

Trade-weighted \$

Policy surprise

Adj. Unconventional $\quad-5.30 * * * \quad-5.81 * * * \quad-8.51 * * *$

Conventional $\quad-6.18 * * * \quad-6.12 \quad-9.88 *$

$\begin{array}{llll}\text { Ratio } & 0.87 & 0.94 & 0.87\end{array}$

Note: The parameter, 0.146 , used to adjust unconventional responses is estimated by regression of unconventional surprises on conventional surprises over the period Feb. 1994-Nov. 2008 (see Table 6, panel A). Figures in the table can be interpreted as the effects of a one bas is point surprise on the exchange rate in basis points. Negative coefficients indicate dollar depreciation. 
Table 8. Robustness Checks of Trade-Weighted Dollar Value Responses to Unconventional and Conventional Policy Surprises, November 2008 - January 2013

Response Window, in minutes

\begin{tabular}{|c|c|c|c|}
\hline & & & \\
\hline & +20 & +60 & +1440 \\
\hline \multicolumn{4}{|l|}{ a. Benchmark } \\
\hline \multicolumn{4}{|l|}{ Policy surprise } \\
\hline Adj. Unconventional & $-5.30 * * *$ & $-5.81 * * *$ & $-8.51 * * *$ \\
\hline Conventional & $-6.18 * * *$ & -6.12 & $-9.88^{*}$ \\
\hline Ratio & 0.86 & 0.95 & 0.86 \\
\hline \multicolumn{4}{|l|}{ b. Wider surprise window } \\
\hline \multicolumn{4}{|l|}{ Policy surprise } \\
\hline Adj. Unconventional & $-5.21 * * *$ & $-6.21 * * *$ & $-9.70 * * *$ \\
\hline Conventional & $-6.12 * * *$ & $-6.19 *$ & $-9.65 *$ \\
\hline Ratio & 0.85 & 1.00 & 1.01 \\
\hline \multicolumn{4}{|l|}{ c. LSAP1 episodes excluded } \\
\hline \multicolumn{4}{|l|}{ Policy surprise } \\
\hline Adj. Unconventional & $-4.16 * * *$ & $-3.09^{* *}$ & -0.31 \\
\hline Conventional & $-6.18 * * *$ & -6.12 & $-9.88^{*}$ \\
\hline Ratio & 0.67 & 0.50 & 0.03 \\
\hline
\end{tabular}

d. Alternative $\gamma$ : sample ends before special facilities

Policy surprise

Adjusted Unconventional $9.69^{* * *}-10.63 * * * \quad-15.56^{* * *}$

Conventional $\quad-6.22 * * \quad-5.27 \quad-12.11$

Ratio $\quad 1.53 \quad 1.70 \quad 1.54$

e. Alternative $\gamma$ : intermeetings excluded

Policy surprise

\begin{tabular}{lccc}
\hline Adj. Unconventional & $-13.66^{* * *}$ & $-14.97^{* * *}$ & $-21.93^{* * *}$ \\
Conventional & $-11.88^{* * *}$ & $-16.79^{* * *}$ & -10.49 \\
Ratio & 1.15 & 0.89 & 2.09
\end{tabular}

Note: $*, * *, * * *$ denote significance at $10 \%, 5 \%, 1 \%$ levels, respectively. Exchange rate changes are in basis point units and surprises are in standardized units, so the figures in the table can be interpreted as the effect of a one standard deviation change in the magnitude of the policy surprise on the exchange rate in basis points. A negative coefficient indicates dollar depreciation. 
Figure 1. Intraday response of foreign currency value of dollar, selected LSAP days

a. An LSAP1 day $(12 / 16 / 2008)$

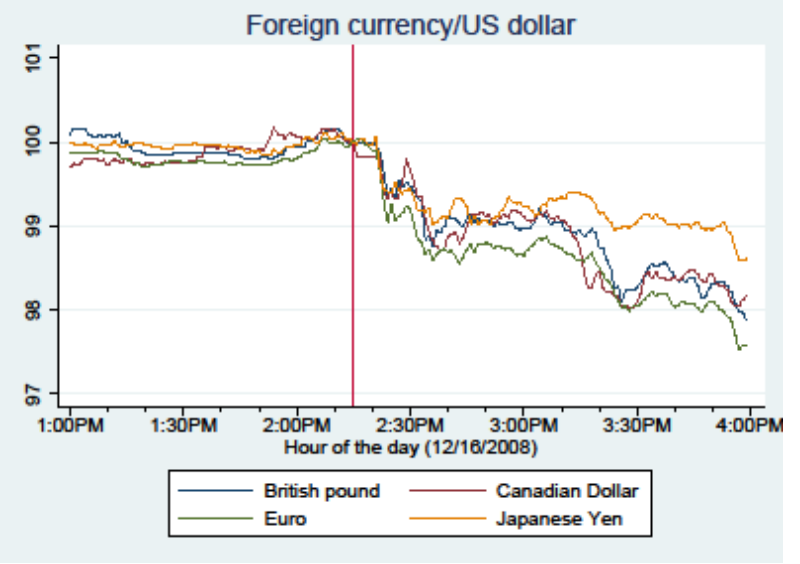

b. An LSAP2 day $(9 / 21 / 2010)$

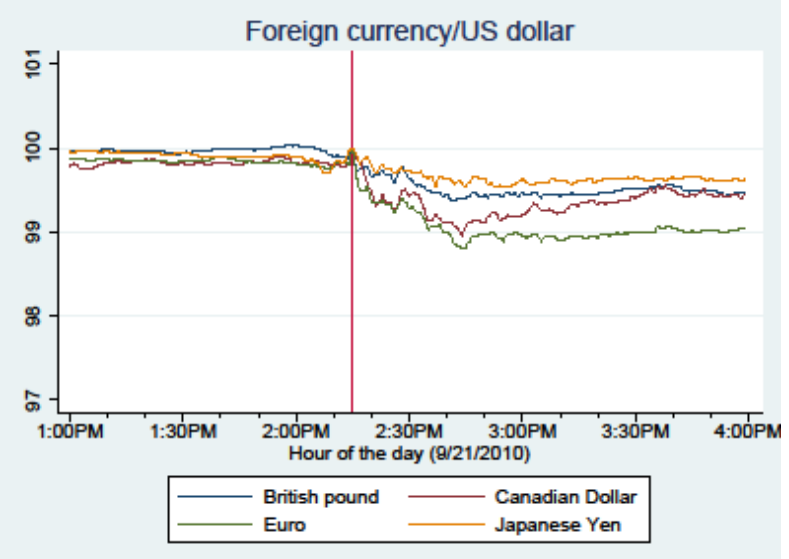

c. An LSAP3 day $(9 / 13 / 2012)$

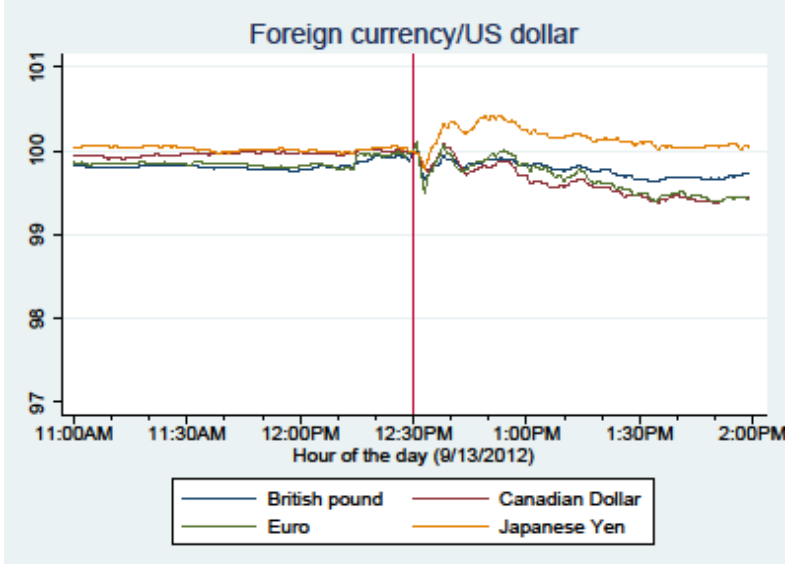


Figure 2. Scatter Plots of Change in Value of Dollar against Unconventional Policy Surprises, November 2008 - January 2013
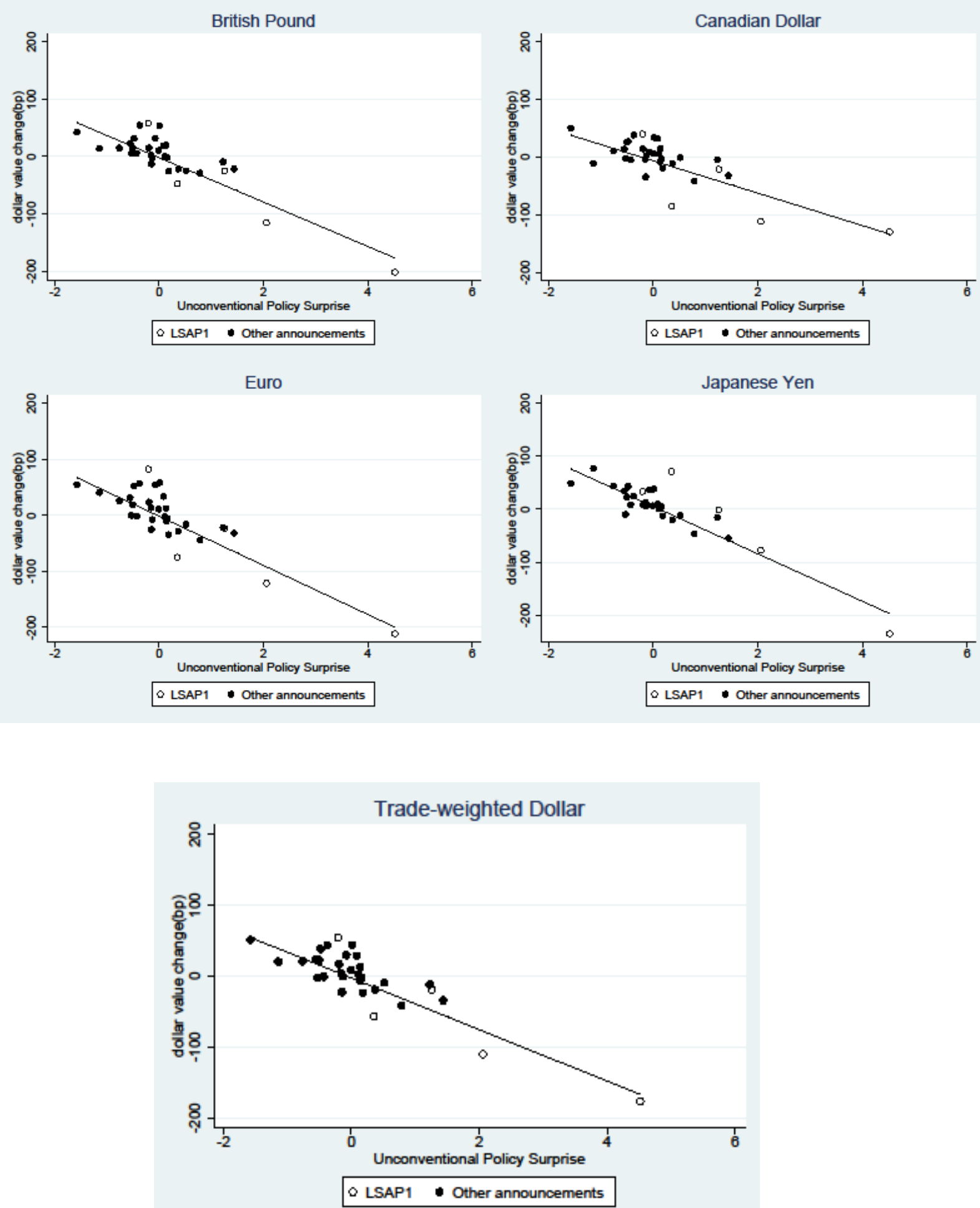

Note: Positive unconventional policy surprises indicate monetary easing and are in standardized units; negative changes in exchange rate indicate depreciation of dollar against the foreign currency in window from 10 minutes before announcement to 20 minutes after. 
Figure 3. Scatter Plots of Change in Value of Dollar against Conventional Policy Surprises February 1994 - October 2008
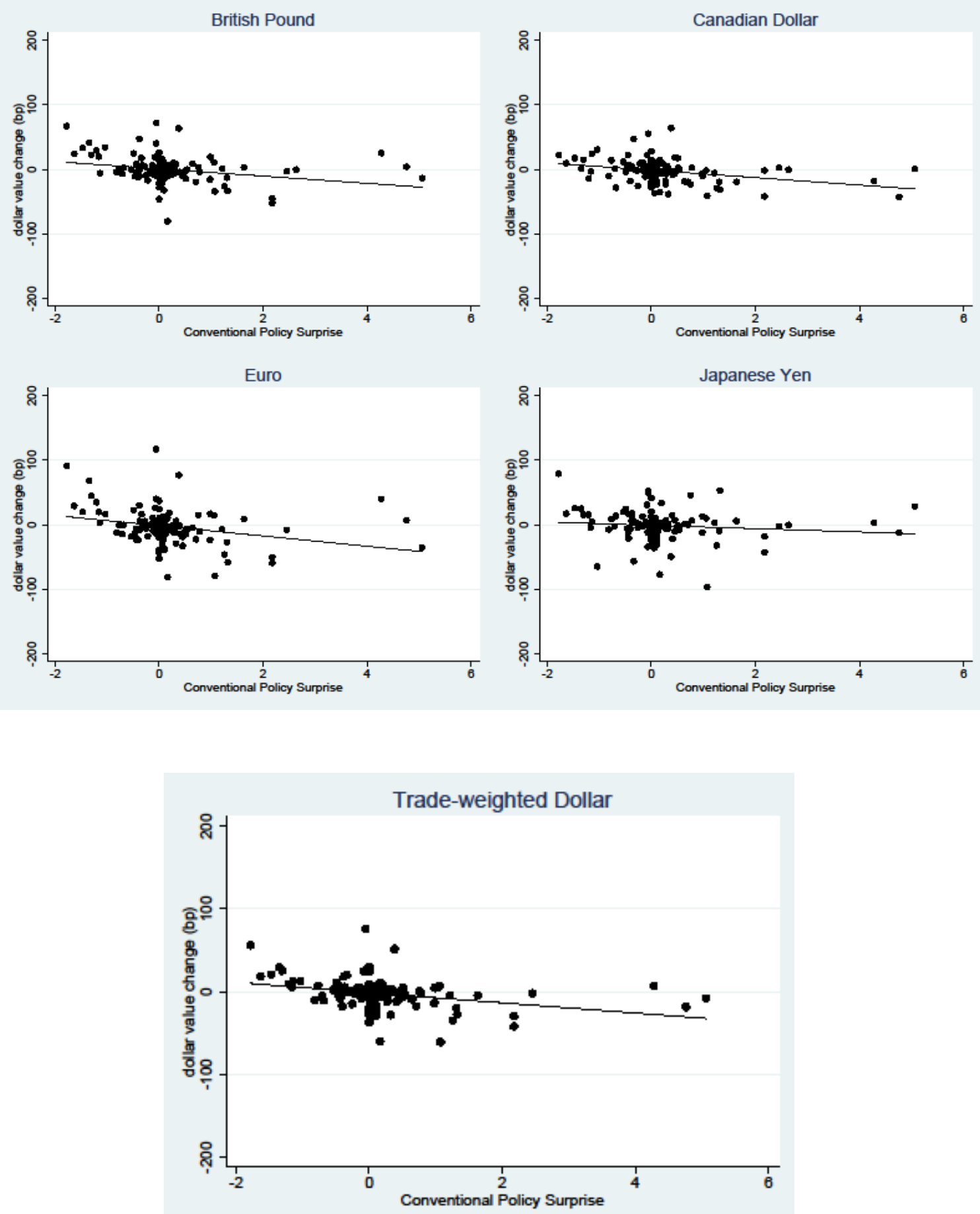

Note: Positive conventional policy surprises indicate monetary easing and are in standardized units; negative changes in exchange rate indicate depreciation of dollar against the foreign currency in window from 10 minutes before announcement to 20 minutes after. 
Figure 4. Scatter Plot of Unconventional and Conventional Monetary Policy Surprises January 1994 -October 2008

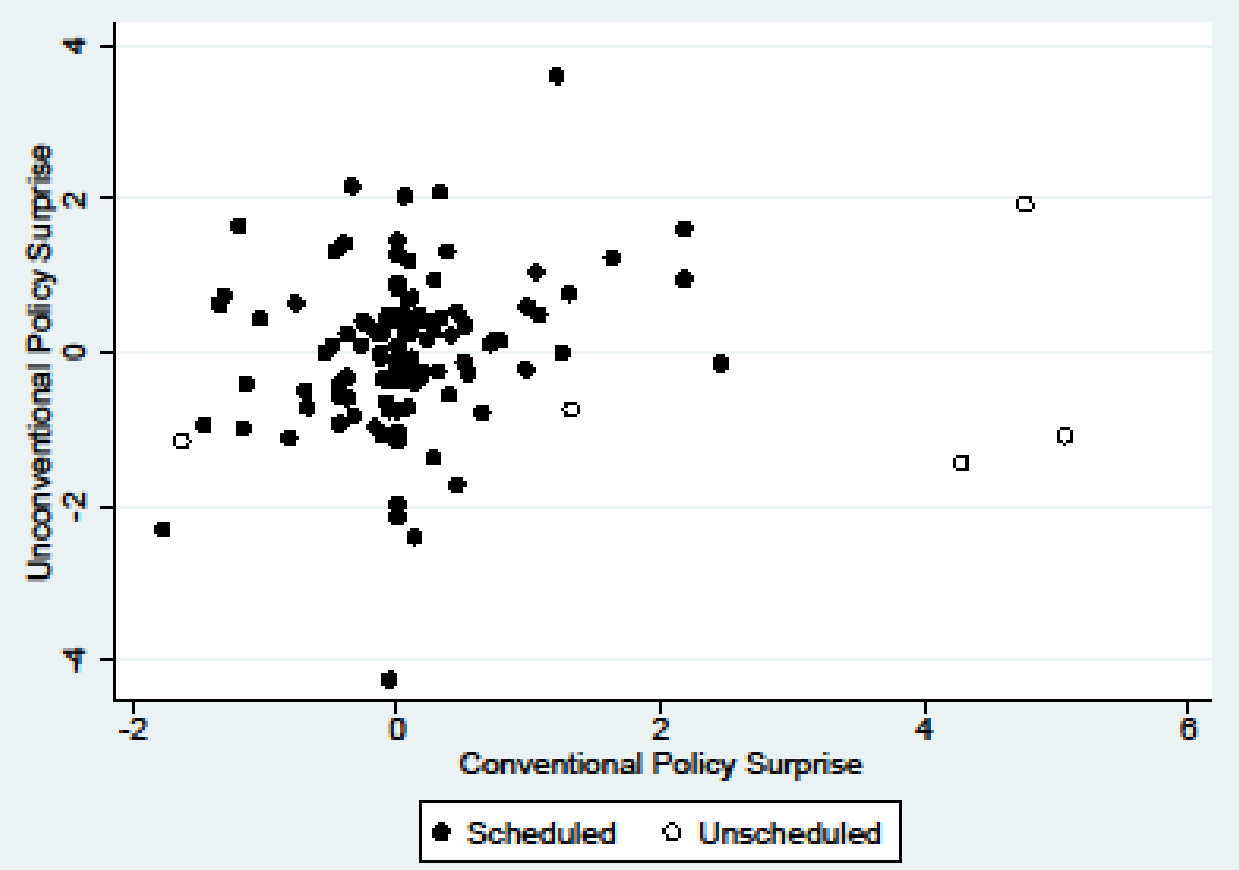

Note: Surprises are in standardized units. Positive surprises indicate monetary policy easing. 